\title{
Typology of dairy production systems from West Parana State based on production indices and feed used
}

\section{Tipologia de sistemas de produção leiteiros do Oeste do Estado do Paraná baseada nos índices produtivos e nos alimentos utilizados}

\author{
Marcelo Eduardo Neumann ${ }^{1 *}$; Maximiliane Alavarse Zambom²; \\ Maichel Jhonattas Lange ${ }^{1}$; Ferenc Istvan Bankuti ${ }^{3}$; Deise Dalazen Castagnara ${ }^{4}$; \\ André Luiz Garcia Dias ${ }^{5}$, Rodrigo Cesar dos Reis Tinini ${ }^{1}$; Tatine Fernandes ${ }^{1}$
}

\begin{abstract}
The dairy industry is characterised by a wide diversity of production systems. In this diverse environment, some of the difficulties can be minimised through the grouping of production units through the study of typology. The objective was to characterise the systems of milk production from West Parana State by considering production rates, area, power, facilities, and marketing of milk. To this end, 735 semistructured interviews with dairy farmers were performed by using a questionnaire for management practices and feed that is used on the farms. To obtain the explanatory variables used for principal component analysis (PCA) and hierarchical cluster analysis (HCA), a homogeneous division of 735 farmers in five groups was used. Ten per cent of producers were randomly selected for the performance of field visits to the properties, where a new questionnaire was applied with specific points regarding feeding management on the property, and feed was collected to determine its composition. The collected data were tabulated and feed was ranked based on the classification proposed by the NRC (2001). Analyses of feed were carried out in the Laboratory of Animal Nutrition of Unioeste. The West Parana State has five groups of dairy production systems. There is great variability in the fresh forages that are used, but maize silage is the main forage utilised for fermented feed, and concentrate supplementation is adopted by more than $60 \%$ of farms during both seasons. Changes in the levels of feed components are high among systems.
\end{abstract}

Key words: Animal feed. Characterisation of production. Composition of foods. Dairy farming.

\section{Resumo}

A pecuária leiteira é caracterizada por ampla diversidade de sistemas de produção. Nesse ambiente diverso, algumas das dificuldades podem ser minimizadas por meio do agrupamento das unidades de produção através do estudo da tipologia. Objetivou-se caracterizar os sistemas de produção de leite do Oeste do Estado do Paraná considerando os índices de produção, área, alimentação, instalações e comercialização do leite. Para tal, foram realizadas 735 entrevistas semiestruturadas, com produtores de leite, utilizando um questionário guia referente a práticas de manejo e dos alimentos utilizados nas

\footnotetext{
${ }^{1}$ Mestres em Zootecnia, Universidade Estadual do Oeste do Paraná, UNIOESTE, Marechal Cândido Rondon, PR, Brasil. E-mail: marcelo.neumann@hotmail.com; maichel_j1@hotmail.com; digotini@hotmail.com; tati-_tati@hotmail.com

2 Prof. Adjunto, Departamento de Zootecnia, UNIOESTE, Marechal Cândido Rondon, PR, Brasil. E-mail: mazambom@hotmail.com

3 Prof. Adjunto, Departamento de Zootecnia, Universidade Estadual de Maringá, UEM, Maringá, PR, Brasil. E-mail: ferencistvan@ gmail.com

4 Prof. Adjunto, Universidade Federal do Pampa, UNIPAMPA, Uruguaiana, RS, Brasil. E-mail: deisecastagnara@yahoo.com.br

5 Pós-Doutorando, UNIOESTE, Marechal Cândido Rondon, PR, Brasil. E-mail: a8algd@gmail.com

* Author for correspondence
} 
propriedades. Para a obtenção das variáveis explicativas usou-se a análise de componentes principais (ACP) e análise de clusters hierárquicos (CHA), obtendo-se a divisão homogênea dos 735 produtores em cinco grupos. Destes foram selecionados ao acaso $10 \%$ dos produtores cada para a realização das visitas a campo nas propriedades, aplicando-se um novo questionário que contemplava pontos específicos do manejo alimentar utilizado na propriedade, bem como a coleta de alimentos para determinação da sua composição. Os dados coletados foram tabulados e os alimentos classificados com base na classificação dos alimentos proposta pelo NRC (2001). As análises dos alimentos foram realizadas no Laboratório de Nutrição Animal da Unioeste. O Oeste do Estado do Paraná possui cinco grupos de sistemas de produção leiteira. Existe grande variabilidade nos alimentos volumosos frescos utilizados, enquanto a silagem de milho é o principal alimento volumoso fermentado e a suplementação concentrada é adotada em mais de $60 \%$ das propriedades nas duas estações. A variação dos teores dos componentes dos alimentos é alta entre os sistemas.

Palavras-chave: Alimentação animal. Caracterização da produção. Composição dos alimentos. Pecuária leiteira.

\section{Introduction}

In dairy farming, understanding the different realities of producers is made possible through production system studies. In these studies, the identification of technical and economic indicators allows us to characterise the productive efficiency ratios of each system and assists in the establishment of public policies (LOPES et al., 2007). Among the determinants of productive efficiency in dairy production systems, herd productivity stands out. In the case of Brazil, for many properties, productivity is still low due to the low specialisation of production systems, especially with regard to feed (ZOCCAL et al., 2008).

When feeding cattle, costs represent $40-80 \%$ of the dry matter (DM) of the diet of many categories that make up the dairy herd (COSTA et al., 2011), and the higher the proportion of concentrate in the diet of animals, the higher the production costs of milk production (SILVA et al., 2008). In addition to the type of feed that is used in herds, the composition of the feed also affects milk production. Knowledge of feed and variation in the intensity of use and composition is very important for the understanding of milk production systems, also known as typology studies.

These studies are usually conducted considering not only the intrinsic characteristics of each farm, but also the feasibility and existing economic barriers for each reality. Through these, it is also possible to establish intervention strategies in order to minimise the heterogeneity of productive actions, promoting social and economic development of small and medium farmers.

For Brazilian dairy production, conducting systems studies is extremely important, since they identify not only the characteristics of milk production, but also the main factors hindering further development of this activity (BRITO et al., 2004), as well as isolated variables that infer and determine those factors.

The activity of dairy farming allows the coexistence of many production systems in the same region or locality. This diversity is possible because the definition of the production system in each factory is the result of association and a combination of factors involving the physical basis, socioeconomic, and cultural factors of each farm (SMITH et al., 2002).

Each production unit coexists within a regional context, where the type and nature of production should be in line with the demands of the product and its marketing. For this reason, studies of production systems allow farms to be studied in the homogeneous groups form. The study of farms in groups of production systems eliminates the need for individual case studies, which are generally expensive and require a long time (SMITH et al., 
2002).

How each component relates to others, and the decisions taken at any point of the system have direct and indirect impacts (BARIONI et al., 2003). Therefore, this study aimed to characterise the milk production systems from West Parana State based on animal performance and feed systems that were adopted during the winter and summer.

\section{Materials and Methods}

This study was conducted in West Parana State. Data collection was performed during the year 2011. The municipality that was considered in the study is located at the Third West Paraná Plateau, between parallels $24^{\circ} 26^{\prime}$ and $24^{\circ} 46^{\prime}$ south latitude and $53^{\circ} 57^{\prime}$ and $54^{\circ} 22^{\prime}$ west longitude, which covers an area of $748 \mathrm{~km}^{2}$. The climate is predominantly a humid temperate type, according to the classification of Köppen and Geiger (1928), and the soil is predominantly a clay soil.

Visits to the properties for milk and feed collection started in August 2012 for the winter season and in January 2013 for the summer season. Sixty-seven properties were visited in the winter, but only 59 were included in the summer due to the abandonment of milk production of the excluded properties, whereas the first sampling consisted of 76 producers.

For the collection of data on the production and milk supply systems, we used a semi-structured questionnaire that was prepared in order to identify at least $80 \%$ of the municipality's milk producers. The questionnaire contained questions about the registration data, characterisation of the owner and the farm, milk production and flock, and feeding management (Table 1). The semi-structured questionnaire was prepared by teachers and students participating in the project and PLEXSUS, based on studies by a group of researchers and technicians regarding the production and quality of milk, while using the techniques for data collection and research in SPL (DEDIEU et al., 1997; SOLANO et al., 2000; DAMASCENO et al., 2008).

The questionnaire was carried out in SEAB (Secretariat of Agriculture and Supply) in West Parana State in November 2011 while using the opportunity to visit the local producers to identify proof of vaccination against FMD. About $80 \%$ of registered milk producers in SEAB answered the questionnaire, thereby totalling 735 producers that were interviewed.

During visits to collect milk and feed during the winter and summer, we applied a new questionnaire, which specifically looked at feed management used on the property. The data that was collected through the questionnaires were tabulated again in Excel, and feed that was used at the properties was classified based on the classification of feed proposed by the NRC (2001).

Also during the visits, individual concentrate samples and other feed that was used in the properties were collected. The samples were kept refrigerated to preserve them, and upon arrival at the Animal Nutrition Laboratory of UNIOESTE, they were processed as described by Silva and Queiroz (2002) for the determination of their chemical composition. Analyses were performed in duplicate for 432 feed types that were collected for the determination of dry matter (DM), mineral matter (MM), crude protein (CP), neutral detergent fibre (NDF), acid detergent fibre (ADF), and ether extract (EE).

The data obtained from the questionnaires were tabulated in Excel and with SPSS 18.0 software, using multivariate statistics. Data were submitted to principal component analysis (PCA) and hierarchical cluster analysis (HCA) to divide the 735 producers into five homogeneous groups.

For the study, each producer's response was considered to be a variable, and was selected by means of the variable selection method (Table 1). Principal component analysis (PCA) identified 
responses that contributed the highest scores in and were true to the original data (Cronbach's terms of explained variance (KUBRUSLY, 2001) $\quad \alpha>0.75$ ).

Table 1. List of variables subjected to principal component analysis and its levels.

\begin{tabular}{ll}
\hline Variables & Levels of each variable and description \\
\hline CUT_AREA (cutting area of hay or silage) & Absolute value \\
PAS_AREA (pasture area) & Absolute value \\
TOT_AREA (total area) & Absolute value \\
TEC_ASS (technical assistance) & $1=$ Not receive technical assistance; $2=$ Receive technical assistance. \\
& $1=$ Milk and other; $2=$ Milk and chicken; $3=$ Milk and pigs; $4=$ Milk \\
ACTIV (activity) & and grains; $5=$ Milk (only) \\
& $1=$ Not receive; $2=$ Receives the amount of milk; $3=$ Receives the \\
BONUS (bonus) & quality of the bed \\
LAC_LEN (lactation length) & Absolute value (months) \\
GENET (genetics) & $1=$ Mongrel, more than two races; $2=$ Crusaders (two races); $3=$ Pure \\
AGE_CAL (age at first calving) & Absolute value (months) \\
CI (calving interval) & Absolute value (months) \\
DAIRY (main dairy) & $1=$ Other; $2=$ Novamix; $3=$ Lacto; $4=$ Nituano; $5=$ Frimesa \\
NUM_TRA (number of transfers) & Absolute value \\
PRO_DAY (production per day) & Absolute value \\
PRO_HEC (production per hectare) & Absolute value \\
TEC_COV (technical cover) & $1=$ Natural mating; $2=$ Artificial insemination \\
TYP_CON (type of concentrate) & $1=$ Not provide; $2=$ Buy the concentrate; $3=$ Manufactures \\
TYP_MIL (type of milking) & concentrate on property \\
TYP_COO (type of cooler) & $1=$ Manual; $2=$ Bucket to Foot; $3=$ Piped \\
& $1=$ Freezer $/$ Refrigerator; $2=$ Cooler immersion; $3=$ Cooler in bulk \\
TYP_SAL (type of salt) & (expansion) \\
& $1=$ Not provide; $2=$ Provides common salt; $3=$ Provides mineral salt; \\
USE_DIP (uses dipping) & $4=$ Provides both \\
NUM_DAI (number of dairy cows) & $1=$ Not utilizes; $2=$ Use only post-dipping; $3=$ Use only pre-dipping; \\
NUM_DRY (number of dry cows) & $4=$ It uses both \\
PER_LAC (percentage of lactating cows) & Absolute value \\
& Absolute value \\
& Absolute value \\
\hline
\end{tabular}

This methodology allows for the exploration of categorical data and is analogous to factor analysis, which allows for the graphical verification of the relationships between categories of variables. So, 23 variables were kept (Table 1), each containing the occurrence of levels so that the creation of these variables followed the concept of the creation of "constructs", that is, an effort to give statistical significance to a concept that is to be evaluated (BARROSO; ARTES, 2003).

After the selection and construction of variables, we proceeded to the tabulation of questionnaire responses in order to obtain a matrix in which the rows correspond to dairy production systems and the columns correspond to the set variables. Also, 
we proceeded to up transformation and encoding of the categories for each variable, thus allowing the use of principal component analysis (CRIVISQUI, 1995; PEREIRA, 1999; MINGOTI, 2005).

Thus, qualitative data were analysed by using principal component analysis (PCA) (LEBART et al., 2000; SMITH et al., 2002; BARROSO; ARTES, 2003), while adopting the software IBM SPSS Statistics 18.0.

A matrix was formed with the response variables, and they were analysed through analysis of hierarchical clusters (AHC) in order to divide the producers into heterogeneous groups with each other and homogeneous groups among the constituent producers (REIS, 2000). The AHC was performed with SPSS 18.0 software.

The analysis of hierarchical clusters to separate the 735 producers into five groups- $10 \%$ of which were selected from the producers of each group to carry out the on-site visits in the properties-totalled 76 chosen properties. Only $10 \%$ of producers were chosen from each group for the financial feasibility of carrying out visits and laboratory analyses, and this percentage is considered to be statistically significant and representative.

The addresses of selected properties were identified and mapped, and the visits were conducted in order to invite producers to a technical meeting in UNIOESTE on 21 March 2012. At this meeting, the project was explained and all of the producers' doubts were clarified. Also on this date, a more specific questionnaire about milk production and management was conducted.

\section{Results and Discussion}

The principal component analysis (PCA) grouped the 735 milk producers that were interviewed into five homogeneous groups (Table 2).

Table 2. Characteristics of the group of dairy production systems.

\begin{tabular}{ccccccc}
\hline Groups & $\begin{array}{c}\text { Number of } \\
\text { properties per } \\
\text { group }\end{array}$ & $\begin{array}{c}\text { Production } \\
\text { daily average } \\
\text { (L/day) }\end{array}$ & $\begin{array}{c}\text { Average } \\
\text { production per } \\
\text { hectare (L/ha) }\end{array}$ & $\begin{array}{c}\text { Average of } \\
\text { dairy cows }\end{array}$ & $\begin{array}{c}\text { Average } \\
\text { production per } \\
\text { cow (L/day) }\end{array}$ & $\begin{array}{c}\text { Production in } \\
\text { 305 days of } \\
\text { lactation (L) }\end{array}$ \\
\hline 1 & 266 & 82 & 6,513 & 8 & 10 & 3,052 \\
2 & 42 & 24 & 6,677 & 3 & 8 & 2,523 \\
3 & 66 & 681 & 28,524 & 34 & 20 & 6,136 \\
4 & 191 & 143 & 12,947 & 11 & 13 & 4,016 \\
5 & 170 & 282 & 13,926 & 19 & 15 & 4,544 \\
\hline Mean & - & 242 & 13,717 & 15 & 13 & 4,054 \\
\hline
\end{tabular}

The two dimensions found by ACP were: principal component 1 (PC1), explaining 49.4\% of the variance, and principal component 2 (MP2), explaining $22.5 \%$ of the variance, which total $71.9 \%$ when grouped together (Table 3), exceeding the recommended minimum of $70 \%$ (BARROSO; ARTES, 2003). Nineteen variables were listed for the major components 1 and 2, which assumed the highest values for each dimension and had a greater contribution to the cumulative variance.

Table 3. Contributions of the components of factor analysis to eigenvalues and explained variance percentage.

\begin{tabular}{cccc}
\hline Components & Eigenvalues & $\begin{array}{c}\text { \% of } \\
\text { variance }\end{array}$ & $\begin{array}{c}\text { Accumulated } \\
\text { variance }\end{array}$ \\
\hline 1 & 8.32 & 49.4 & 49.4 \\
2 & 5.76 & 22.5 & 71.9 \\
\hline
\end{tabular}


The identified groups showed significant differences in the main parameters that addressed their classification (Table 2). Group 1 included properties that adopt the milk production system as the main alternative source of income, but dedicated to the production, small land area and small number of animals, with low average daily production (82 L).
In the graphic representation of the grouping of properties into five production system groups, the quadrants that were obtained from the intersection of the axes of the main components (MP1 and MP2) enable an interpretation of the characteristics related to the milk production for each group (Figure 1).

Figure 1. Representation of the ACP factorial and clusters of systems.

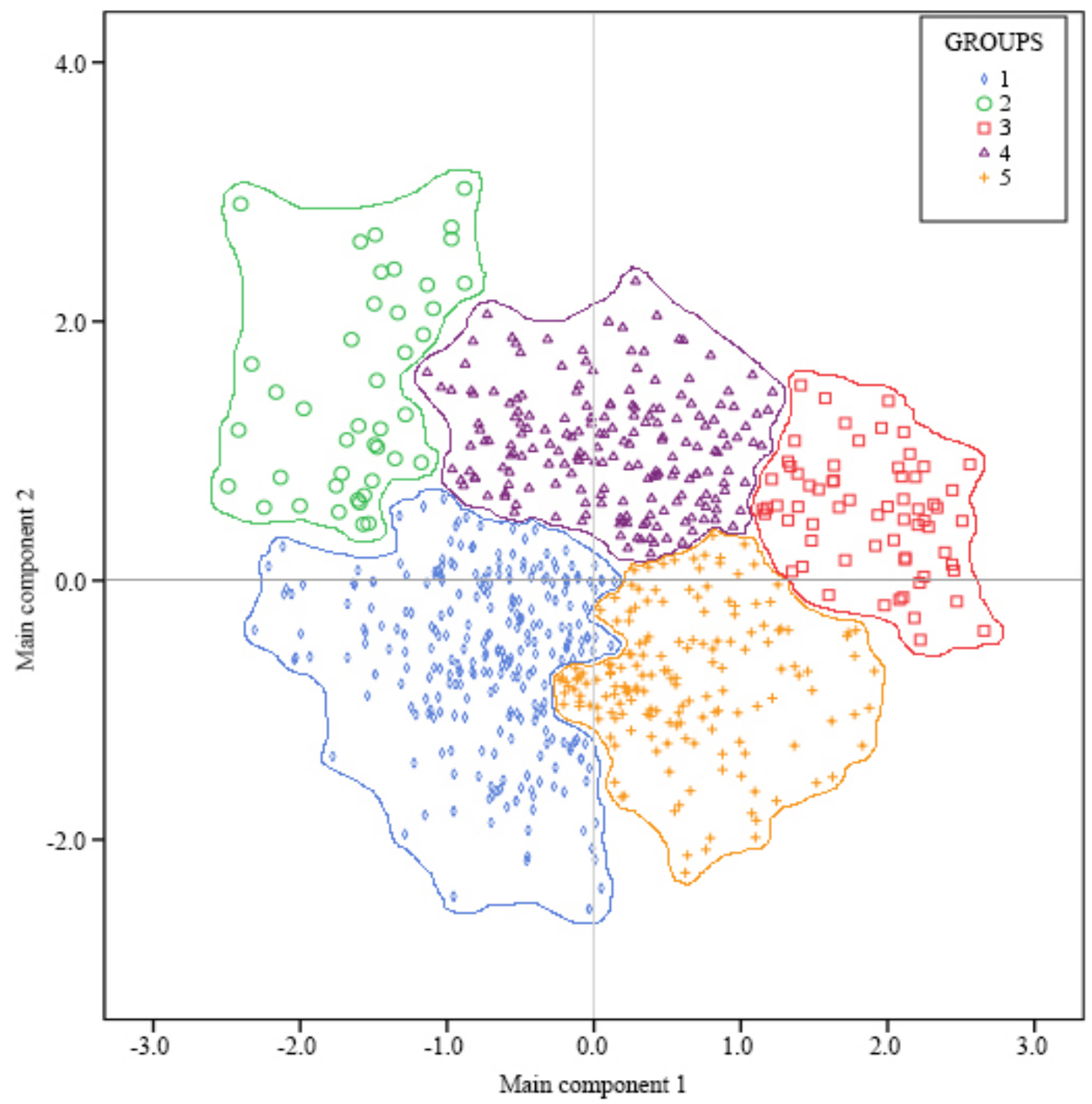

The same features in group 1 are present in group 2, but these particular properties indicate diversification of production systems, development of other activities within the limits of the property, and utilisation of dairy farming as a source of secondary income. Among the activities that were developed in these properties as primary sources of income, are agricultural cultivation with grain 
production, pig breeding and commercial poultry.

Group 3 stands out from the others because it is the one with the highest production rates, so that the members of this group are positioned on the positive side of the axes MP1 and MP2 (Figure 1). The producers of this group adopt the necessary measures for the growth and expansion of activity on the property, such as the use of sanitary practices, management of livestock and pastures, and the availability of improvements and equipment (IPARDES, 2009). In groups 4 and 5, the dairy business is the main financial source of the property, though the groups differ in the daily production (Table 2).

During visits to the sampled properties, which totalled 67 in the summer and 59 in the winter, feed was identified and is listed in Table 4, which was classified into groups based on the classification of feed proposed by the NRC (2001).

Table 4. List of feed found in the visited properties, classification according to NRC (2001) feed classes, and percentage of farms using feed in the winter and summer seasons.

\begin{tabular}{|c|c|c|c|}
\hline Class & Feed & Winter $(\%)$ & Summer (\%) \\
\hline \multirow{2}{*}{ Dry bulky } & Black oat (hay) & 2.99 & 0.00 \\
\hline & Tifton 85 (hay) & 29.85 & 28.81 \\
\hline \multirow{14}{*}{ Green bulky } & Alfalfa (pasture) & 0.00 & 1.69 \\
\hline & Aries (pasture) & 1.49 & 1.69 \\
\hline & Black oat (pasture) & 31.34 & 5.08 \\
\hline & Brachiaria brizantha (pasture) & 1.49 & 0.00 \\
\hline & Sugar cane (prick) & 7.46 & 3.39 \\
\hline & Elephant (pasture) & 8.96 & 13.56 \\
\hline & African star (pasture) & 8.96 & 13.56 \\
\hline & Mato grosso (pasture) & 0.00 & 3.39 \\
\hline & Maize (whole plant) & 4.48 & 0.00 \\
\hline & Mombasa (pasture) & 0.00 & 3.39 \\
\hline & Always green (pasture) & 1.49 & 1.69 \\
\hline & Sudan (pasture) & 0.00 & 3.39 \\
\hline & Tifton 85 (pasture) & 38.81 & 61.02 \\
\hline & Vaquero (pasture) & 0.00 & 1.69 \\
\hline Fermented bulky & Maize (silage) & 67.16 & 62.71 \\
\hline \multirow{7}{*}{ Energy concentrate } & Yucca (chopped root) & 2.99 & 3.39 \\
\hline & Yucca mass (silage) & 20.90 & 13.56 \\
\hline & Maize (ground grits) & 5.97 & 6.78 \\
\hline & Maize (pollard) & 2.99 & 3.39 \\
\hline & Maize (wet grain silage) & 5.97 & 0.00 \\
\hline & Soybean (shell) & 0.00 & 1.69 \\
\hline & Whole Wheat (brain) & 14.93 & 10.17 \\
\hline \multirow{3}{*}{ Protein concentrate } & Cotton (core) & 1.49 & 0.00 \\
\hline & Cotton (brain) & 2.99 & 0.00 \\
\hline & Soybean (brain) & 5.97 & 3.39 \\
\hline Commercial mixture & Commercial concentrate & 67.16 & 69.49 \\
\hline Homemade mixture & Homemade concentrate & 14.93 & 16.95 \\
\hline
\end{tabular}


For dry bulky were observed for the variety of oats, hay, and Tifton 85, while the variety of green bulky that was used in animal feed was greater with several annual and perennial grasses, some hibernal, and other estival, in addition to the legume alfalfa. In the class of green bulky, the pastures of Tifton 85 stood out at $61.02 \%$ of the properties in the summer and $38.81 \%$ of the properties in the winter. Tifton 85 is a forage grass that is traditionally used in western Paraná, both for grazing and for hay production (CASTAGNARA et al., 2011).

It is worth noting that some properties adopted new forage technologies for animals in order to provide new forage species that are distinct from those that are traditionally used, such as the Aries grass (Panicum maximum cv. Aries), the Sudan grass (Sorghum sudanense), and the Vaquero grass (Cynodon dactylon cv. Vaquero). However, in the same way, some properties still insist on using old grasses that are recommended for gardening, with low production potential and composition (Table 5), such as the Mato thick grass (Paspalum notatum) (MACIEL et al., 2008) and Always Green (Axonopus compressus) (KOJOROSKI-SILVA et al., 2011).

The supply of forages in pieces was also observed, so that sugar cane and the whole maize plant were used in winter in $7.46 \%$ and $4.48 \%$ of the properties, respectively, while in the summer only chopped sugar cane was used in $3.39 \%$ of the properties.

Sugar cane has a low nutritional value (SIQUEIRA et al., 2012) (Table 5), which limits its use in dairy herds, and is only recommended for average, low production animals. However, the high dry matter yield per unit area is the main factor that still encourages its use (SIQUEIRA et al., 2012). The whole maize plant also has a high dry matter production potential per unit area, but it has a nutritional value that is higher than the cane (ZEOULA et al., 2003) (Table 5), thus giving it the potential to feed dairy cattle.

In the case of fermented bulky, the only feed that was used in the properties was maize silage, which was traditionally produced and used in the region of the West Parana State to feed dairy cattle. The use of this feed presented as highlight, was observed in $67.16 \%$ of the properties in the summer and in $62.71 \%$ of the properties in the winter.

Of the collected and analysed feed, we would like to highlight some that showed different values than those found in the majority of the literature. It may be noted, as described in Table 5, that the Brachiaria brizantha averaged 15.03\% CP and the maize whole plant contained $10.36 \% \mathrm{CP}, 18.77 \%$ DM, and 7.70\% MM, while Valadares Filho et al. (2006) obtained a value of $10.65 \%$ CP for Brachiaria brizantha and $7.06 \% \mathrm{CP}, 32.97 \% \mathrm{DM}$, and $3.99 \%$ of $\mathrm{MM}$ for the maize whole plant. The differences that were observed for the entire foot of maize were due to the different plant harvesting stages, because the visited properties had maize plants that were harvested for grinding and animal feeding around the time of the vegetative stage (bolting) when the highest proportion of leaves in plants was present. Consequently, there was a lower dry matter content and a higher percentage of crude protein when compared to whole plant maize silage-a point that was studied by Valadares Filho et al. (2006). The differences that were observed for the Brachiaria are also due to the use of pig slurry (MONDARDO et al., 2011) and chicken manure (SANTOS et al., 2014) to fertilise pastures and to cultivate Brachiaria, because Piatã usually provides higher levels of crude protein when compared to other cultivars of the same genus (ORRICO JUNIOR et al., 2013).

For dry bulky were observed for the variety of oats, hay, and Tifton 85 , while the variety of green bulky that was used in animal feed was greater with several annual and perennial grasses, some hibernal, and other estival, in addition to the legume alfalfa. In the class of green bulky, the pastures of Tifton 85 stood out at $61.02 \%$ of the properties in the summer and $38.81 \%$ of the properties in the winter. Tifton 85 is a forage grass that is traditionally used in western Paraná, both for grazing and for hay production (CASTAGNARA et al., 2011). 
Table 5. Average composition (\%) and standard deviation (SD) of forages.

\begin{tabular}{|c|c|c|c|c|c|c|c|}
\hline Feedstuff & & $\mathrm{DM}^{1}$ & $\mathrm{MM}^{2}$ & $\mathrm{CP}^{3}$ & $\mathrm{NDF}^{4}$ & $\mathrm{ADF}^{5}$ & $\mathrm{EE}^{6}$ \\
\hline \multirow{3}{*}{ Alfalfa (grassland) } & Mean & 17.40 & 11.28 & 10.70 & 31.67 & 22.77 & 3.75 \\
\hline & $S D$ & 0.00 & 0.00 & 0.00 & 0.00 & 0.00 & 0.00 \\
\hline & $n$ & 1 & 1 & 1 & 1 & 1 & 1 \\
\hline \multirow{3}{*}{ Aries (grassland) } & Mean & 19.90 & 13.45 & 14.47 & 54.70 & 32.19 & 2.04 \\
\hline & $S D$ & 0.43 & 0.50 & 0.78 & 0.24 & 1.80 & 0.13 \\
\hline & $n$ & 2 & 2 & 2 & 2 & 2 & 2 \\
\hline \multirow{3}{*}{ Oatmeal black (hay) } & Mean & 69.09 & 9.36 & 13.52 & 55.39 & 32.38 & 3.17 \\
\hline & $S D$ & 3.10 & 0.13 & 0.38 & 0.11 & 0.47 & 0.32 \\
\hline & $n$ & 2 & 2 & 2 & 2 & 2 & 2 \\
\hline \multirow{3}{*}{ Oatmeal black (grassland) } & Mean & 15.56 & 10.87 & 15.48 & 53.28 & 33.36 & 3.55 \\
\hline & $S D$ & 3.76 & 2.30 & 3.90 & 7.59 & 4.79 & 1.05 \\
\hline & $n$ & 24 & 24 & 24 & 24 & 24 & 24 \\
\hline \multirow{3}{*}{ Brachiaria brizantha (grassland) } & Mean & 13.32 & 8.22 & 15.03 & 58.45 & 35.12 & 1.16 \\
\hline & $S D$ & 0.00 & 0.00 & 0.00 & 0.00 & 0.00 & 0.00 \\
\hline & $n$ & 1 & 1 & 1 & 1 & 1 & 1 \\
\hline \multirow{3}{*}{ Sugar cane (sting) } & Mean & 32.29 & 3.55 & 4.93 & 58.70 & 33.30 & 2.64 \\
\hline & $S D$ & 6.29 & 0.25 & 1.34 & 7.32 & 4.70 & 0.40 \\
\hline & $n$ & 7 & 7 & 7 & 7 & 7 & 7 \\
\hline \multirow{3}{*}{ Elephant (grassland) } & Mean & 17.75 & 12.20 & 8.47 & 62.65 & 36.96 & 1.92 \\
\hline & $S D$ & 3.49 & 2.24 & 2.13 & 6.16 & 4.19 & 0.28 \\
\hline & $n$ & 14 & 14 & 14 & 14 & 14 & 14 \\
\hline \multirow{3}{*}{ African star (grassland) } & Mean & 25.48 & 10.93 & 14.79 & 60.28 & 31.88 & 2.84 \\
\hline & $S D$ & 4.53 & 2.14 & 3.54 & 4.47 & 3.09 & 1.23 \\
\hline & $n$ & 14 & 14 & 14 & 14 & 14 & 14 \\
\hline \multirow{3}{*}{ Mato grosso (grassland) } & Mean & 22.92 & 9.32 & 12.26 & 67.38 & 34.82 & 2.56 \\
\hline & $S D$ & 0.01 & 0.90 & 4.18 & 3.17 & 5.44 & 0.05 \\
\hline & $n$ & 2 & 2 & 2 & 2 & 2 & 2 \\
\hline \multirow{3}{*}{ Maize (whole plant) } & Mean & 18.77 & 7.70 & 10.36 & 61.19 & 33.22 & 2.32 \\
\hline & $S D$ & 2.46 & 1.21 & 1.58 & 2.09 & 1.42 & 0.24 \\
\hline & $n$ & 3 & 3 & 3 & 3 & 3 & 3 \\
\hline \multirow{3}{*}{ Maize (silage) } & Mean & 34.07 & 4.72 & 6.90 & 43.58 & 23.51 & 2.93 \\
\hline & $S D$ & 5.54 & 0.80 & 1.23 & 6.97 & 4.03 & 0.95 \\
\hline & $n$ & 82 & 82 & 82 & 82 & 82 & 82 \\
\hline \multirow{3}{*}{ Mombasa (grassland) } & Mean & 17.58 & 12.97 & 9.99 & 61.12 & 36.98 & 1.61 \\
\hline & $S D$ & 1.42 & 0.04 & 2.21 & 0.98 & 1.13 & 0.21 \\
\hline & $n$ & 2 & 2 & 2 & 2 & 2 & 2 \\
\hline \multirow{3}{*}{ Always green (grassland) } & Mean & 23.05 & 11.77 & 17.50 & 56.93 & 30.27 & 3.40 \\
\hline & $S D$ & 3.75 & 0.31 & 0.97 & 4.07 & 2.03 & 0.35 \\
\hline & $n$ & 2 & 2 & 2 & 2 & 2 & 2 \\
\hline \multirow{3}{*}{ Sudan (grassland) } & Mean & 15.50 & 12.16 & 14.39 & 53.11 & 34.36 & 2.20 \\
\hline & $S D$ & 0.61 & 0.45 & 0.27 & 0.17 & 3.77 & 0.11 \\
\hline & $n$ & 2 & 2 & 2 & 2 & 2 & 2 \\
\hline \multirow{3}{*}{ Tifton 85 (hay) } & Mean & 84.11 & 8.26 & 10.27 & 67.24 & 33.49 & 1.91 \\
\hline & $S D$ & 2.30 & 0.96 & 0.94 & 3.03 & 2.33 & 0.60 \\
\hline & $n$ & 37 & 37 & 37 & 37 & 37 & 37 \\
\hline \multirow{3}{*}{ Tifton 85 (grassland) } & Mean & 24.19 & 9.84 & 10.50 & 60.27 & 31.09 & 2.39 \\
\hline & $S D$ & 4.20 & 1.28 & 1.56 & 5.19 & 2.84 & 0.40 \\
\hline & $n$ & 62 & 62 & 62 & 62 & 62 & 62 \\
\hline \multirow{3}{*}{ Vaquero (grassland) } & Mean & 21.06 & 9.10 & 16.53 & 59.32 & 28.19 & 1.71 \\
\hline & $S D$ & 0.00 & 0.00 & 0.00 & 0.00 & 0.00 & 0.00 \\
\hline & 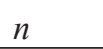 & 1 & 1 & 1 & 1 & 1 & 1 \\
\hline
\end{tabular}

${ }^{1}$ Dry Matter; ${ }^{2}$ Mineral Matter; ${ }^{3}$ Crude Protein; ${ }^{4}$ Neutral Detergent Fiber; ${ }^{5}$ Acid Detergent Fiber; ${ }^{6}$ Ether Extract. 
It is worth noting that some properties adopted new forage technologies for animals in order to provide new forage species that are distinct from those that are traditionally used, such as the Aries grass (Panicum maximum cv. Aries), the Sudan grass (Sorghum sudanense), and the Vaquero grass (Cynodon dactylon cv. Vaquero). However, in the same way, some properties still insist on using old grasses that are recommended for gardening, with low production potential and composition (Table 5), such as the Mato thick grass (Paspalum notatum) (MACIEL et al., 2008) and Always Green (Axonopus compressus) (KOJOROSKI-SILVA et al., 2011).

The supply of forages in pieces was also observed, so that sugar cane and the whole maize plant were used in winter in $7.46 \%$ and $4.48 \%$ of the properties, respectively, while in the summer only chopped sugar cane was used in $3.39 \%$ of the properties.

Sugar cane has a low nutritional value (SIQUEIRA et al., 2012) (Table 5), which limits its use in dairy herds, and is only recommended for average, low production animals. However, the high dry matter yield per unit area is the main factor that still encourages its use (SIQUEIRA et al., 2012). The whole maize plant also has a high dry matter production potential per unit area, but it has a nutritional value that is higher than the cane (ZEOULA et al., 2003) (Table 5), thus giving it the potential to feed dairy cattle.

In the case of fermented bulky, the only feed that was used in the properties was maize silage, which was traditionally produced and used in the region of the West Parana State to feed dairy cattle. The use of this feed presented as highlight, was observed in $67.16 \%$ of the properties in the summer and in $62.71 \%$ of the properties in the winter.
Of the collected and analysed feed, we would like to highlight some that showed different values than those found in the majority of the literature. It may be noted, as described in Table 5, that the Brachiaria brizantha averaged $15.03 \% \mathrm{CP}$ and the maize whole plant contained $10.36 \% \mathrm{CP}, 18.77 \%$ $\mathrm{DM}$, and $7.70 \% \mathrm{MM}$, while Valadares Filho et al. (2006) obtained a value of $10.65 \%$ CP for Brachiaria brizantha and $7.06 \% \mathrm{CP}, 32.97 \% \mathrm{DM}$, and $3.99 \%$ of MM for the maize whole plant. The differences that were observed for the entire foot of maize were due to the different plant harvesting stages, because the visited properties had maize plants that were harvested for grinding and animal feeding around the time of the vegetative stage (bolting) when the highest proportion of leaves in plants was present. Consequently, there was a lower dry matter content and a higher percentage of crude protein when compared to whole plant maize silage-a point that was studied by Valadares Filho et al. (2006). The differences that were observed for the Brachiaria are also due to the use of pig slurry (MONDARDO et al., 2011) and chicken manure (SANTOS et al., 2014) to fertilise pastures and to cultivate Brachiaria, because Piatã usually provides higher levels of crude protein when compared to other cultivars of the same genus (ORRICO JUNIOR et al., 2013).

Other grasses that have good nutritional contents were also analysed. For instance, African star averaged $14.79 \% \mathrm{CP}, 60.28 \% \mathrm{NDF}$, and $2.84 \% \mathrm{EE}$, and some of these components were close to those found by Favoreto et al. (2008) at 13.95\% of CP, $69.34 \% \mathrm{NDF}$, and $1.26 \%$ of EE.

The African Star (Axonopus compressus) also presented with a high protein content, as it is not a specific grass for cattle production. This may be due to the high application of organic fertilisers such as swine manure, which is common in the region (MONDARDO et al., 2011). 
In Vaquero grass (Cynodon dactylon cv. Vaquero), which can be found in pastures that are considered to contain new technologies and are specific to cattle farming pastures, there is a high protein content of $16.53 \%$-a value that is close to that obtained by Machado (2014), which was $18.18 \%$ crude protein.

Of the feed concentrates, the commercial mixture was used to a greater extent, and was adopted as concentrated feed in $67.16 \%$ of the properties in the winter and in $69.49 \%$ of the properties in the summer.

Another option for reducing feeding costs is the use of alternative feed sources (SILVA et al., 2005) such as cassava dough, which was found in $20.90 \%$ of the properties in winter and $13.56 \%$ in summer, soybean hulls, which has a good amount of fibre (Table 6) present in $1.69 \%$ of properties in the summer, as well as cottonseed meal and optimal protein (Table 6), which were used at 2.99 to $1.49 \%$ of properties in winter, respectively.

Of the concentrated energy, ground maize and wheat bran as well as derivatives and by-products of cassava, such as the root of the mass of chopped cassava, were used. In this particular case, manioc concentrate was classified as effective and not as an energy fibre due to the low crude protein content of less than $2 \%$. Even as protein concentrate was observed in some properties, soybean meal, cotton, and cotton seed were found to have similar compositions between the samples that were collected due to the low standard deviation (Table $6)$.

Mixtures of concentrated ingredients (feed) have been identified separately based on a skew in the feed NRC (2001) class, whereas were observed in properties the commercial mixtures (bought at a local market), as well as in homemade mixtures (prepared on the properties). However, only $14.93 \%$ of the properties in the winter and $16.95 \%$ of the properties in the summer prepared the concentrate mixture on the property. In the presence of quality technical assistance, the adoption of this technique is promising from the point of view of cost savings with regards to the feed safety of animals, due to the knowledge of the origin and condition of the feed that was used.

When considering the feed concentrates (Table 6), there were some mixed results when compared to other studies. It may be noted that although there is some standardisation of the plants for the commercial concentrate, there was a high standard deviation between the samples. Some examples can be found in the crude protein content, in which the variation between samples was 11.09 to $31.04 \%$ and the neutral detergent fibre was 8.91 to $38.38 \%$.

The ground maize (grits) was the feed with the most variation when compared to the literature for NDF and ADF, with $9.46 \%$ and $2.98 \%$, respectively. According to Valadares Filho et al. (2006), ground maize has levels of $17.09 \%$ NDF and $5.95 \%$ of ADF in dry matter. Zambom et al. (2001) observed values of $5.44 \%$ for the ADF ground maize. These variations are due to the characteristics of maize that was obtained on the farm and the conditions of the time and storage in the warehouses of processors companies and own property (CARVALHO et al., 2009).

Maize pollard, which is also called cracked maize and cob, is especially used on small farms in times of feed shortage or as a substitute for grain maize due to its low cost (PORTO et al., 2008). NDF and ADF for maize pollard also resulted in big differences, with $22.84 \%$ and $9.53 \%$, respectively. Meanwhile, the literary values were close to $61.32 \%$ and $17.65 \%$ for NDF and ADF (VALADARES FILHO et al., 2006). 
Table 6. Average composition (\%) and standard deviation (SD) of feed concentrate.

\begin{tabular}{|c|c|c|c|c|c|c|c|}
\hline Feedstuff & & ${ }^{1} \mathrm{DM}$ & ${ }^{2} \mathrm{MM}$ & ${ }^{3} \mathrm{CP}$ & ${ }^{4} \mathrm{NDF}$ & ${ }^{5} \mathrm{ADF}$ & ${ }^{6} \mathrm{EE}$ \\
\hline \multirow{3}{*}{ Cotton (core) } & Mean & 91.72 & 5.22 & 23.03 & 50.96 & 27.67 & 6.53 \\
\hline & $S D$ & 0.00 & 0.00 & 0.00 & 0.00 & 0.00 & 0.00 \\
\hline & $n$ & 1 & 1 & 1 & 1 & 1 & 1 \\
\hline \multirow{3}{*}{ Cotton (bran) } & Mean & 90.98 & 4.38 & 28.10 & 45.05 & 26.40 & 6.63 \\
\hline & $S D$ & 0.71 & 0.14 & 1.17 & 1.86 & 1.11 & 0.14 \\
\hline & $n$ & 2 & 2 & 2 & 2 & 2 & 2 \\
\hline \multirow{3}{*}{ Homemade concentrate } & Mean & 84.14 & 5.68 & 21.16 & 19.01 & 8.48 & 4.83 \\
\hline & $S D$ & 6.34 & 2.93 & 7.25 & 7.29 & 3.50 & 3.23 \\
\hline & $n$ & 20 & 20 & 20 & 20 & 20 & 20 \\
\hline \multirow{3}{*}{ Commercial concentrate } & Mean & 87.45 & 6.60 & 19.60 & 21.46 & 8.95 & 3.80 \\
\hline & $S D$ & 3.25 & 2.08 & 3.69 & 7.61 & 3.83 & 2.94 \\
\hline & $n$ & 86 & 86 & 86 & 86 & 86 & 86 \\
\hline \multirow{3}{*}{ Yucca (root sting) } & Mean & 32.54 & 3.74 & 2.14 & 8.33 & 4.60 & 1.63 \\
\hline & $S D$ & 5.54 & 0.67 & 0.47 & 1.93 & 0.93 & 0.17 \\
\hline & $n$ & 4 & 4 & 4 & 4 & 4 & 4 \\
\hline \multirow{3}{*}{ Yucca (silage mass) } & Mean & 15.69 & 2.38 & 2.36 & 34.79 & 27.22 & 0.86 \\
\hline & $S D$ & 3.64 & 0.29 & 0.19 & 3.30 & 2.30 & 0.30 \\
\hline & $n$ & 22 & 22 & 22 & 22 & 22 & 22 \\
\hline \multirow{3}{*}{ Maize (ground grits) } & Mean & 80.47 & 1.49 & 8.73 & 9.46 & 2.98 & 3.91 \\
\hline & $S D$ & 8.65 & 0.27 & 0.58 & 1.16 & 0.46 & 0.98 \\
\hline & $n$ & 8 & 8 & 8 & 8 & 8 & 8 \\
\hline \multirow{3}{*}{ Maize (pollard) } & Mean & 84.59 & 1.36 & 8.19 & 22.84 & 9.53 & 2.39 \\
\hline & $S D$ & 2.67 & 0.23 & 0.74 & 2.59 & 0.80 & 0.46 \\
\hline & $n$ & 4 & 4 & 4 & 4 & 4 & 4 \\
\hline \multirow{3}{*}{ Maize (silage grain wet) } & Mean & 73.91 & 1.25 & 9.07 & 8.36 & 2.74 & 5.05 \\
\hline & $S D$ & 7.39 & 0.13 & 0.78 & 0.69 & 0.22 & 0.66 \\
\hline & $n$ & 4 & 4 & 4 & 4 & 4 & 4 \\
\hline \multirow{3}{*}{ Soybean (bark) } & Mean & 87.79 & 4.63 & 11.75 & 61.85 & 40.73 & 2.17 \\
\hline & $S D$ & 0.00 & 0.00 & 0.00 & 0.00 & 0.00 & 0.00 \\
\hline & $n$ & 1 & 1 & 1 & 1 & 1 & 1 \\
\hline \multirow{3}{*}{ Soybean (bran) } & Mean & 87.47 & 6.75 & 47.61 & 12.84 & 10.56 & 2.03 \\
\hline & $S D$ & 0.79 & 0.42 & 1.09 & 1.37 & 0.70 & 0.49 \\
\hline & $n$ & 6 & 6 & 6 & 6 & 6 & 6 \\
\hline \multirow{3}{*}{ Whole wheat (bran) } & Mean & 87.36 & 4.51 & 17.40 & 32.41 & 10.39 & 2.71 \\
\hline & $S D$ & 0.76 & 0.51 & 1.34 & 4.06 & 1.06 & 0.74 \\
\hline & $n$ & 16 & 16 & 16 & 16 & 16 & 16 \\
\hline
\end{tabular}

${ }^{1}$ Dry Matter; ${ }^{2}$ Mineral Matter; ${ }^{3}$ Crude Protein; ${ }^{4}$ Neutral Detergent Fiber; ${ }^{5}$ Acid Detergent Fiber; ${ }^{6}$ Ether Extract.

Soybean meal has widely varying values when compared to other studies. In this case, we observed $47.61 \% \mathrm{CP}$ and $2.03 \%$ of EE; levels of $51.41 \% \mathrm{CP}$ and $3.45 \% \mathrm{EE}$, and $48.78 \% \mathrm{CP}$ and $1.71 \% \mathrm{EE}$ were observed by Zambom et al. (2001) and Valadares Filho et al. (2006), respectively.
There is great variability in fresh forages that were used, but maize silage is the main forage for fermented feed and concentrate supplementation, and is adopted by most of the properties in the two seasons. The variety in feed composition between production systems compared to other authors 
is high, probably due to the fertiliser used, which varies for each production system.

As for the systems groups in this study, some factors differentiate them from each other, highlighting the difficulties encountered in organising daily activities, also due the variation of physical structures of the farms and a reduced livestock control of herds.

Other relevant information on the characteristics of production systems is the difficulty encountered in the return of capital generated for the activity itself. Under these conditions, the income generated on the farm every month is practically all committed to family expenses, so that only a small percentage of that revenue could be returned to dairy farming in the form of investment in technologies that could contribute to increased production rates.

\section{Conclusion}

The West Parana State has five groups of milk production systems with different technological and production levels, those being characterised by having mostly small farms and family farming.

Given the difficulties of organisational order within each system and financial order because of the return on capital generated for their own activity, milk production proved to be a great ally for sustenance, mainly for small producers in the studied systems.

Also, because of the great diversity of roughage and concentrate feed in this study, it is clear that the farmer has several alternatives to supplement the herd, choosing the one that is suitable both economically and practically.

\section{References}

BARIONI, L. G.; MARTHA JÚNIOR, G. B.; RAMOS, A. K. B.; VElOSO, R. F.; RODRIGUES, D. C.; VILELA, L. Planejamento e gestão do uso de recursos forrageiros na produção de bovinos em pastejo. In:
SIMPÓSIO SOBRE MANEJO DA PASTAGEM, 20., 2003, Piracicaba. Anais... Piracicaba: FEALQ, 2003. p. 105-154.

BARROSO, L. P.; ARTES, R. Análise multivariada. In: SIMPÓSIO DE ESTATÍSTICA APLICADA À EXPERIMENTAÇÃO AGRONÔMICA, 2003, Lavras. Anais... Lavras: Universidade Federal de Lavras, 2003. CD-ROM.

BRITO, J. R. F. Adoção de boas práticas agropecuárias em propriedades leiteiras da Região Sudeste do Brasil como um passo para a produção de leite seguro. Acta Scientiae Veterinariae, Porto Alegre, v. 32, n. 2, p. 125131, 2004.

CARVALHO, D. C. O.; ALBINO, L. F.; VARGAS JUNIOR, J. G.; TOLEDO, R. S.; OLIVEIRA, J. E.; SOUZA, R. M. True digestibility of amino acids and digestible amino acids values of corn samples submitted to different drying temperatures and storage periods. Revista Brasileira de Zootecnia, Viçosa, MG, v. 38, n. 5, p. 850-856, 2009.

CASTAGNARA, D. D.; AMES, J. P.; NERES, M. A.; OLIVEIRA, P. S. R.; SILVA, F. B.; MESQUITA, E. E.; STANGARLIN, J. R.; FRANZENER, G. Use of conditioners in the production of Tifton 85 grass hay. Revista Brasileira de Zootecnia, Viçosa, MG, v. 40, n. 10, p. 2083-2090, 2011.

COSTA, L. T.; SILVA, F. F.; VELOSO, C. M.; PIRES, A. J. V.; ROCHA NETO, A. L.; MENDES, F. B. L.; RODRIGUES, E. S. O.; SILVA, V. L. Economical analysis of different concentrate levels for dairy crossbred fed sugar cane based diets. Revista Brasileira de Zootecnia, Viçosa, MG, v. 40, n. 5, p. 1155-1162, 2011.

CRIVISQUI, E. Présentation de l'analyse factorielle des correspondances simples et multiples: programe de Recherche et D'Enseignement em Statistique Appliquée (PRESTA). Bruxelles: Université Libre de Bruxelles, 1995. $162 \mathrm{p}$.

DAMASCENO, J. C.; BOUNDERMÜLLER FILHO, A.; RAMOS, C. E. C. O.; SANTOS, J. C.; SANTOS, G. T. O Papel do homem na gestão e controle de qualidade da produção de leite. In: SANTOS, G. T.; UHLIG, L.; BRANCO, A. F.; JOBIM, C. C.; DAMASCENO, J. C.; CECATO, U. (Ed.). Inovação tecnológica na cadeia produtiva do leite e a sustentabilidade da pecuária leiteira. Maringá: EDUEM, 2008. p. 271-284.

DEDIEU, B.; CHABANET, G.; JOSIEN, E.; BECHEREL, F. Organisation du pâturage et situations contraignantes en travail: démarche d'étude et examples en élevage bovin viande de zone herbagère. Fourrages, Versailles, v. 149, n. 1, p. 21-36, 1997. 
FAVORETO, M. G.; DERESZ, F.; FERNANDES, A. M.; VIEIRA, R. A. M.; FONTES, C. A. A. Nutritional analysis of stargrass cv. Africana for dairy cattle under rotational grazing. Revista Brasileira de Zootecnia, Viçosa, MG, v. 37, n. 2, p. 319-327, 2008.

INSTITUTO PARANAENSE DE DESENVOLVIMENTO ECONÔMICO E SOCIAL - IPARDES. Caracterização Socioeconômica da atividade leiteira no Paraná: sumário executivo. Instituto Paranaense de Desenvolvimento Econômico e Social e Instituo Paranaense de Assistência Técnica e Extensão Rural. Curitiba: IPARDES, 2009. 29 p.

KOJOROSKI-SILVA, C. M.; SCHEFFER-BASSO, S. M.; CARNEIRO, C. M.; GUARIENTI, M. Morphological development of Emerald, Carpetgrass and Tifton 419 turfgrasses. Ciência e Agrotecnologia, Lavras, v. 35, n. 3, p. 471-477, 2011.

KÖPPEN, W.; GEIGER, R. Klimate der Erde. Gotha: Verlag Justus Perthes, 1928. (wall-map 150x200 cm).

KUBRUSLY, L. S. Um procedimento para calcular índices a partir de uma base de dados multivariados. Pesquisa Operacional, Rio de Janeiro, v. 21, n. 1, p. $107-$ 117, 2001.

LEBART, L. Statistique exploratoire multidimensionnelle. $3^{\text {th }}$ ed. Paris: Dunod, 2000. 439 p.

LOPES, M. A.; CARDOSO, M. G.; CARVALHO, F. M.; LIMA, A. L. R.; DIAS, A. S.; CARMO, E. A. Effect of the feedlot system on the profitability of the dairy production systems in Lavras (MG) region, Brazil, in 2004 and 2005. Ciência Animal Brasileira, Goiânia, v. 8, n. 3, p. 359-371, 2007.

MACHADO, I. W. J. Trocas gasosas e desidratação do capim Vaquero: valor nutricional no armazenamento do feno. 2014. Dissertação (Mestrado em Zootecnia) Universidade Estadual do Oeste do Paraná, Marechal Cândido Rondon.

MACIEL, C. D. G.; POLETINE, J. P.; AQUINO, C. J. R.; FERREIRA, D. M.; MAIO, R. M. D. Composição florística da comunidade infestante em gramados de Paspalum notatum no município de Assis, SP. Planta Daninha, Viçosa, MG, v. 26, n. 1, p. 57-64, 2008.

MINGOTI, S. A. Análise de dados através de métodos de estatística multivariada: uma abordagem aplicada. Belo Horizonte: UFMG, 2005. 297 p.

MONDARDO, D.; CASTAGNARA, D. D.; OLIVEIRA, P. S. R.; ZOZ, T.; MESQUITA, E. E. Produção e composição químico-bromatológica da aveia preta fertilizada com doses crescentes de dejeto líquido suíno. Revista Ciência Agronômica, Fortaleza, v. 42, n. 2, p. 509-517, 2011.
NATIONAL RESEARCH COUNCIL - NRC. Nutrient requirements of dairy cattle. $7^{\text {th }}$ ed. Washington: National Academy of Sciences, 2001. 381 p.

ORRICO JUNIOR, M. A. P.; ORRICO, A. C. A.; CENTURION, S. R.; SUNADA, N. S.; LUCAS JUNIOR, J. Nutritive value of Piata grass fertilized with different doses of biofertilizers. Revista Agrarian, Dourados, v. 6, n. 21, p. 312-319, 2013.

PEREIRA, J. C. R. Análise de dados qualitativos: estratégias metodológicas para as ciências da saúde, humanas e sociais. São Paulo: EDUSP, 1999. 157 p.

PORTO, M. O.; PAULINO, M. F.; VALADARES FILHO, S. C.; SALES, M. F. L.; DETMANN, E.; CAVALLI, J. Corn, in different forms, in multiple supplements for finishing crossbred steers on pasture during rainly season: performance and nutrition parameters. Revista Brasileira de Zootecnia, Viçosa, MG, v. 37, n. 12, p. 2251-2260, 2008.

REIS, E. A análise de clusters e as aplicações às ciências empresariais: uma visão crítica da teoria dos grupos estratégicos. In: REIS, E.; FERREIRA, M. A. M. (Ed.). Temas em métodos quantitativos 1. Lisboa: Edições Sílabo, 2000, p. 205-238.

SANTOS, L. B.; CASTAGNARA, D. D.; BULEGON, L. G.; ZOZ, T.; OLIVEIRA, P. S. R.; GONCALVES JUNIOR, A. C.; NERES, M. A. Mineral nitrogen substitution by chicken litter in succession oat/corn. Bioscience Journal, Uberlândia, v. 30, n. 3, p. 272-281, 2014.

SILVA, D. J.; QUEIROZ, A. C. Análise de alimentos: métodos químicos e biológicos. $3^{\text {th }}$ ed. São Paulo: UFV, 2002. $235 \mathrm{p}$.

SILVA, H. A.; KOEHLER, H. S.; MORAES, A.; GUIMARAES, V. A.; HACK, E.; CARVALHO, P. C. F. Evaluation of the economic viability of milk production on pasture and supplements in the region of Campos Gerais - Parana, Brazil. Ciência Rural, Santa Maria, v. 38, n. 2, p. 445-450, 2008.

SILVA, H. G. O.; PIRES, A. J. V.; SILVA, F. F.; VELOSO, C. M.; CARVALHO, G. G. P.; CEZARIO, A. S.; SANTOS, C. C. Apparent digestibility of diets containing cocoa meal and palm kernel cake in lactating goats. Pesquisa Agropecuária Brasileira, Brasília, v. 40, n. 4, p. 405-411, 2005.

SIQUEIRA, G. R.; ROTH, M. T. P.; MORETTI, M. H.; BENATTI, J. M. B.; RESENDE, F. D. Uso da cana-deaçúcar na alimentação de ruminantes. Revista Brasileira de Saúde e Produção Animal, Salvador, v. 13, n. 4, p. 991-1008, 2012. 
SMITH, R. R.; MOREIRA, V. M.; LATRILLE, L. L. Characterization of dairy productive systems in the Tenth Region of Chile using multivariate analysis. Agricultura Técnica, La Únion, v. 62, n. 3, p. 375-395, 2002.

SOLANO, C.; BERNUÉS, A.; JOAQUIN, N.; FERNANDEZ, W.; HERRERO, M. Relationships between management intensity and structural and social variables in dairy and dual-purpose systems in Santa Cruz, Bolivia. Agricultural Systems, Amsterdam, v. 65, n. 3, p. 159-177, 2000.

VALADARES FILHO, S. C.; MAGALHÃES, K. A.; ROCHA JUNIOR, V. R. Tabelas brasileiras de composição de alimentos para bovinos. $2^{\text {th }}$ ed. Viçosa, MG: UFV, 2006. 239 p.
ZAMBOM, M. A.; SANTOS, G. T.; MODESTO, E. C.; ALCADE, C. R.; GONCALVES, G. D.; SILVA, D. C.; SILVA, K. T.; FAUSTINO, J. O. Nutritional value of soybean hulls, soybean meal, ground corn and wheat meal for cattle. Acta Scientiarum, Maringá, v. 23, n. 4, p. 937-943, 2001.

ZEOULA, L. M.; BELEZE, J. R. F.; CECATO, U.; JOBIM, C. C.; GERON, L. J. V.; PRADO, O. P. P.; FALCAO, A. J. S. Evaluation of five corn hybrids (Zea mays, L.) at different maturity stages. 4. Dry matter digestibility, organic matter and neutral detergent fiber (FDN) of the vegetative portion and whole plant. Revista Brasileira de Zootecnia, Viçosa, MG, v. 32, n. 3, p. 567575, 2003.

ZOCCAL, R.; CARNEIROS, A. V.; JUNQUEIRA, R.; SOARES, T. A.; ZAMAGNO, M. Zoneamento da produção de leite no Brasil. In: SIMPÓSIO DO NÚCLEO DE ESTUDOS EM BOVINOCULTURA, 2008, Rio de Janeiro. Anais... Rio de Janeiro: UFRRJ, 2008. CD-ROOM. 
